\title{
Discourse Markers in College English Listening Instruction: An Empirical Study of Chinese Learners
}

\author{
Jianfeng Zhang \\ College of Humanities and Foreign Languages, Xi'an University of Science and Technology \\ Lintong District, Xi'an Shaanxi, 710600, China \\ E-mail: zhangjianfeng091024@126.com
}

Received: December 21, 2011

Accepted: December 30, 2011

Published: March 1, 2012

doi:10.5539/elt.v5n3p46

URL: http://dx.doi.org/10.5539/elt.v5n3p46

This study is sponsored by the Instructional Research Project (JG10044) of Xi'an University of Science and Technology.

\begin{abstract}
Discourse markers can clearly indicate the organization of discourse, remind the hearer of the preceding and the following contents, and express clearly the concrete speech acts. The aims of this study are to explore the relationship between the discourse-marker-based model and listening comprehension as well as the different effects of such a kind of instruction on liberal arts and science students. 120 Chinese college students of non-English major, who are from two different departments of Xi'an University of Science and Technology, are the research subjects. An experiment has been carried out by applying the theory of discourse markers to enhance the English listening skill proficiency. Based on the results of the data analysis, the conclusion can be drawn that discourse-marker-based listening instruction can improve students' listening comprehension of non-English major and liberal arts students benefit more from discourse-marker-based listening instruction.
\end{abstract}

Keywords: Discourse markers, Listening comprehension, College English listening instruction

\section{Introduction}

Most languages in the world have a range of words or lexical expressions, which do not belong to any of the major syntactic categories, which do not indicate objects, events, and whose meanings do not contribute to the conceptual meaning of utterance in which they occur (Wilson, 2000), but work as informative markers and instruct utterance interpretation. These kinds of words or expressions, such as "you know; I mean; well; so; okay" are called discourse markers (henceforth DMs), and play an important role in the communication. Since the 1970s, interest in DMs has turned into a "growing industry" (Fraser, 1999) in linguistics with growing interest in pragmatic and contextual aspects of utterance interpretation. A wealth of studies has been done on this topic. Research on DMs and similar phenomena have expanded continually throughout the 1980s and 1990s, with the result that such items now figure prominently not only in pragmatic and discourse analytic researches but also in the studies on sociolinguistic topics ranging from gender variation to code-switching (Schourup,1999).

During the past twenty years, the study of DMs has developed very quickly in linguistics, with dozens of articles appearing yearly (Aijmer, 2002). Numerous studies have attempted to specify the meaning or functions of an individual DM or small sets of DMs in various languages, and several attempts have been made to characterize DMs in a more general way (Schiffrin, 1987).

Many scholars have done a lot of theoretical and empirical studies on DMs, such as but ( Schiffrin, 1987; Norrick, 2002), and (Bestgen, 1998; Fraser, 1988), you know ( Macaulay, 2002), so and therefore (Fraser, 1996; Blakemore, 1992) in English; alors, donc and bon (Hansen, 1997) in French; and dui bu dui (Chen, 2001) in Chinese. However, most of them have carried out their studies in native speakers' language environment and the empirical studies mainly concentrate on its effect on writing and speaking. Since listening comprehension, as one of language input skills, occupies an important status in second language (henceforth L2) learning, which greatly affects the improvement of other language skills, it is very necessary and significant to study the relationship between DMs and listening comprehension as well as the application of DMs to listening instruction. 
In this study, 120 Chinese college students of non-English major, who are from two different departments of Xi'an University of Science and Technology, are the research subjects. An experiment has been carried out by applying the theory of discourse markers to enhance the English listening skill proficiency. The aims of this study are to explore the relationship between the discourse-marker-based model and listening comprehension as well as the different effects of such a kind of instruction on liberal arts and science students.

\section{Background to the Study}

\subsection{Discourse Markers}

The term discourse markers has different meanings for different groups of researchers and there is no agreement about what elements in a particular language should be referred to as DMs and studies on DMs have been done under a variety of overlapping labels. Among them there are sentence connectives, semantic conjuncts, cue phrases, discourse connectives, discourse-deictic items, discourse operators, discourse particles, fillers, makers of pragmatic structure, parenthetical phrases, phatic connectives, pragmatic connectives, pragmatic expressions, pragmatic formatives, pragmatic markers, pragmatic operators, pragmatic particles, pragmatic function words, reaction makers, so on and so forth.

Among those researches, Schiffrin is one of the most influential scholars who has studied the discourse markers in detail and has firmly established the term "discourse markers" in linguistic research. The definition that has received greatest attention today is Schiffrin's preliminary working definition of DMs as "sequentially dependent elements which bracket units of talk" (Schiffrin, 1987). Later, she gives a more elaborate description of the markers as "proposing the contextual coordinates within which an utterance is produced and designed to be interpreted" (Schiffrin, 1987).On the basis of Schiffrin's study of DMs, Redeker calls discourse markers "discourse operators" and proposes the definition of her own: "...a word or phrase--for instance, a conjunction, adverbial, comment clause, interjection - that is uttered with the primary function of bringing to the listeners' attention, a particular kind of linkage of the upcoming utterance with the immediate discourse context." (Redeker, 1991)

In Fraser's work (1987), he writes about a group of expressions which he calls "pragmatic formative" but later calls "pragmatic markers" (1996). DMs, as a grammatical category, are seen as a subclass of pragmatic markers. Specifically, he characterizes a DM as a linguistic expression which: (a) has a core meaning which can be enriched by the context; and (b) signals the relationship that the speakers intend between the utterance the DM introduces and the foregoing utterance.

Based upon the Relevance Theory, Blakemore, the most influential representative of this perspective, maintains that DMs can be regarded as linguistically specified constraints on cognitive context. She calls them "discourse connectives": "expressions that constrain the interpretation of the utterances which contain them by virtue of the inferential connections they express." (Blakemore, 1987) Thus the DMs are regarded as items which cognitively limit the hearer's interpretation in that they indicate the speaker's intention. So the employment of DMs is one means to make contextual assumptions more accessible to the hearer.

From what was noted above, differences can be seen we see in defining DMs by different scholars. Obviously, the different concentrations and perspectives reflect their conceptions of the overall definitions of DMs in the communication. But from these definitions, some generalizations can be made about DMs: in general, DMs are a range of words or expressions drawn from classes of conjunctions, adverbials, prepositional phrases and other syntactic categories. They are used to express the speaker's communicative purposes, i.e. to make the utterance more fluent and easy to understand. What's more, they have no contribution to the meaning of the utterance, that is to say, if the DMs are removed from the utterance, the semantic relationship between the elements they connect remains the same; and without the DMs, the grammaticality of the utterance must still be intact.

\subsection{Characterization of DMs}

\section{Connectivity}

The connectivity of DMs is most often taken to be a necessary characteristic though it is conceived in different ways. Schiffrin and Fraser's definitions specify that DMs relate two textual units, thus contributing to inter-utterance coherence. They claim that DMs mark boundaries between verbal activities and imply relations between two textual units. However, Blakemore points out that it is undesirable to distinguish discourse-internal uses of a connective so. For example:

(1) A: You take the first turning on the left.

B: So we don't go past the university. 
(2) [Seeing someone return home with parcels]

So you've spent all your money.

In both uses so marks an implicated conclusion and in example (2), the speaker derives from observation of a state of affairs and uses the DM so to draw his/her conclusion. Therefore, DMs may link their host utterance not only to the linguistic co-text, but also to the context in a wider sense.

Optionality

DMs are frequently claimed to be optional in two distinct senses. They are almost universally regarded as syntactically optional in the sense that removal of a DM does not alter the grammaticality of its host sentence. However, DMs are also widely claimed to be optional in the further sense that they do not enlarge the possibilities for semantic relationship between the elements they associate. Therefore, if a DM is omitted, the relationship it signals is still available to the hearer, though no longer explicitly cued. Utterances (3) and (4), for example, may be understood in roughly the same way.

(3) The others are going to Stock. However, I am going to Paris.

(4) The others are going to Stock. I am going to Paris.

Thus, while DMs are typically said to "display" or "reflect" existing propositional connections rather than create them, they are also commonly said to "reinforce" or "clue" the interpretation intended by the speaker.

Non-truth-conditionality

DMs are generally thought to contribute nothing to the truth-conditions of the proposition expressed by an utterance (Hansen, 1997). Some (Fraser, 1996) take this to mean that DMs do not affect the truth-conditions of sentences, but support has grown for the view that truth-conditions pertain not to sentences but to mental representations. Thus Kempson (1986): "truth-theoretic content is defined solely with respect to propositional forms of the language of inference". In neither view are so-called DMs seen as contributing to the truth-theoretic content associated with the marked utterance.

The non-truth-conditionality of DMs distinguishes them from uses of "content" words, including manner adverbial uses of words like sadly. If the DM you know is taken away from Utterance (5), the truth-condition of the utterance will not be changed whereas the truth-condition of Utterance (6) will be changed if we omit sadly as seen in the following examples:

(5) Owens is a respected drama critic. You know, she has written...

(6) Sadly, he left his home.

Connectivity, optionality, and non-truth-conditionality are all frequently taken together to be necessary attributes of DMs. The remaining features such as weak clause association, initiality, orality and multi-categoriality are less consistently regarded as criteria for DMs status; therefore, they will not be presented in details in this study.

\subsection{Listening Comprehension and Discourse Markers}

\subsubsection{The Nature of Listening Comprehension}

Listening is a complex activity difficult to investigate. Research in listening is in an exploratory stage. At present, despite much theoretical and empirical research, a consensus on a definition of listening comprehension has not yet been reached. Being a vital skill for almost all interaction, listening is also the most important medium for input in learning a foreign language. Krashen (1982) puts forward "input hypothesis" and "comprehensible input" which indicate the importance of listening. Krashen holds that the comprehensible input is an important factor in second language acquisition and a comprehension-before-production approach can facilitate language acquisition particularly in the early stages.

Chaudron and Richards (1986), Anderson and Lynch (1988), Rost (1990) emphasize that listening comprehension must acknowledge that many processes work together in an interactive, overlapping and simultaneous fashion. Rost (1990) sums this up: “...a listener's interpretation continuously changes throughout a speech event; it is not accurate to speak of sequential stages in listening, starting with speech perception. It is more accurate to think of the processes of perception and interpretation as continuous, overlapping and mutually informing from spoken utterances after the words have been recognized; their meanings computed and the syntax of the utterance has been parsed."

Psycholinguists suggest that listening is a process in which the listener has to use syntactic and semantic 
information to identify acoustic cue; and it involves various linguistic and extra-linguistic factors. In other words, listening comprehension is not a simple decoding process, but a process combining decoding process with reconstructing meaning. In the process, listeners' participation, social-cultural knowledge, pragmatic knowledge and linguistic knowledge are very important.

Generally speaking, listening comprehension is a complex process. In human communication, listeners not only listen to others, they also have to comprehend what others are talking about. Listening comprehension includes the auditory perception and all sorts of cognitive competence in attaining the goal of understanding. Therefore, listening comprehension is a composite process of memorizing, generalizing, predicting and language transforming.

\subsubsection{Discourse Markers and Listening Comprehension: Relevant Studies}

Chaudron and Richard (1986) look at the influence of DMs on the comprehension of academic lecture, and they conclude that DMs can facilitate comprehension. They consider two kinds of discourse signals in a lecture: macro-markers and micro-markers. The former signals the macro-structure (e.g. what I'm going to talk about today...) of a lecture through highlighting the major information in the lecture and the sequencing or importance of that information. The latter (e.g. and, so, well) indicates links between sentences with the lecture or function as fillers.

Hron et al. compare the listening comprehension of two version of a lengthy English text with and without discourse markers. They conclude that listeners who have heard the text with additional DMs reproduce significantly more macro-propositions than those who have heard the non-marked version. (Rubin, 1994)

Thompson (2003) focuses on the roles of text-structuring DMs in signaling the lager-scale organization of academic talks. He finds that the occurrence of DMs in authentic undergraduate lectures and in talks appearing in EAP (English for Academic Purposes) listening skills materials can help an audience form a coherent "mental map" of the overall talk.

Generally speaking, there are only a few studies concerning the effect of DMs on listening. All the studies to some extent affirm that DMs can facilitate listening comprehension. However, most of them have carried out their studies in the native language environment. Few of them explore English DMs in EFL environment.

\section{Research Methodology}

\subsection{Research Questions}

The study attempts to answer the following research questions:

1) Does discourse-marker-based listening instruction (henceforth DMLI) improve students' proficiency of listening comprehension?

2) Does DMLI have the same influence on students with different majors (science students and liberal arts students)?

\subsection{Subjects}

One hundred and twenty students from Xi'an University of Science and Technology are chosen as the subjects of this experiment. This is because as freshmen the students are very active in listening class, and have a certain interest in listening. They have learned English for at least six years, so they have enough ability and knowledge to receive the training of listening strategies. Besides, the two groups are parallel classes, having the same English teacher, the same teaching materials, and the same listening class time (2 classes per week). Furthermore, the classroom environment is also the same. Therefore, to a certain extent, the differences caused by other factors can be controlled.

These two groups are intact classes selected from Management School and Chemistry \& Chemical Engineering Department of Xi'an University of Science and Technology. Class 1 is chosen as the Experimental Class (henceforth EC), which includes 30 science students and 30 liberal arts students, receiving the DMLI; whereas Class 2 is chosen as the Control Class (henceforth CC), which includes 30 science students and 30 liberal arts students, receiving the normal listening instruction. The EC consists of 60 students with 38 males and 22 females, while CC is made up of 32 males and 28 females.

\subsection{Research Procedures}

The experiment lasts for a whole semester (18 weeks). The one-semester training research begins in September, 2010 and ends in February, 2011. During this period, the researcher uses a method of illustration-interaction-induction-internalization in the Experimental Class to reinforce the students' knowledge 
of DMs.

Like the case of grammar teaching noted by McCarthy and Carter (1995), traditional and well-established "Three-P of Presentation-Practice-Production" may need be revised to involve students in greater awareness of the use of DMs in listening. The researcher proposes 4-I methodology, "Illustration-Interaction-Induction-Internalization".

\subsubsection{Illustration}

"Illustration" refers to presentation of authentic DMs in context and use. According to Blakemore (1992), the researcher divides DMs into four types and in the listening class, the researcher has introduced the functions and use of these four types respectively.

1) Discourse markers introducing contextual implications

In listening comprehension, the speaker sometimes presents a proof and then a conclusion by using a DM to constrain the listener's inferential process involved in interpretation. DMs such as so, therefore, thus, then, as a consequence, accordingly, in this case, as a result can be grouped to play this role. For example:

(1) Son: The Smiths have a party today.

Father: So what?

(2) She's your teacher. Therefore, you must respect her.

(3) The bank has closed all day. Thus we couldn't make a withdrawal.

The researcher introduces those DMs and analyzes functions of them. In (1), so introduces a contextual implication of an assumption that has been made accessible. The father is asking what conclusion he is expected to draw from the son's remark. In (2), the first proposition is being asserted as a reason to prove that the speaker is recommending the listener respect the teacher. Therefore is to constrain the relevance of the proposition in the preceding utterance. In (3), thus signals that the segment following is to be taken as expressing a conclusion which the proposition of the first segment provides justification for.

2) Discourse markers strengthening existing assumptions

If the speaker is suggesting that this is something the listener already knows, the speaker exploits DMs only to increase the strength of the listener's conviction of the assumption conveyed in the previous utterance. DMs which aim to increase strength of the existing assumption may include: after all, you see, you know, because, since, moreover, furthermore, also, indeed, and, in addition, what is more. For example:

(4) She's not here. You see, it is Monday.

Clearly, the listener is expected to supply a connection between Mondays and going out. After hearing the second segment, the listener believes that "She goes out every Monday."

The speaker provides additional evidence by using furthermore or besides for an assumption derived from the previous utterance. For example:

(5) Man: Will you make pancakes?

Woman: I haven't really got time tonight. Furthermore/Besides, there's no milk.

The woman gives one more reason that she will not make pancakes because she has no time today and because there's no milk.

3) Discourse markers introducing denials

On some occasions the speaker intends to contradict come elements of the interpretation of a preceding utterance. Then the speaker must use DMs which can function to deny the assumption conveyed in the preceding utterance. In this case, the listener will have to abandon the existing assumption so that the contradiction between the new information and the old information is solved. DMs such as but, however, nevertheless, yet, still, though, conversely, on the other hand can be grouped in this type.

(6) Man: You were born in North Philadelphia?

Woman: No. I was born in South Philadelphia. But I move to North Philadelphia when I was a year old.

In this example, but has two functions: providing the requested information, correcting the man's fault; explaining the connection between the man and woman, in other words, a face-saving effort which is cooperative. 
Other DMs, such as however, still or nevertheless, can play the same role in utterance interpretation, although they are not completely interchangeable in all contexts. The researcher has made students clear that DMs introduce denial by virtue of the fact that they lead the hearer to eliminate an existing assumption conveyed in the previous utterance.

4) Discourse markers specifying the roles of utterance

There are other DMs to specify what roles the utterances they play in the communication, such as also, too, either, well, by the way, anyway, first, finally, speaking of, return to my point.

(7) Simon's got a laser printer too.

The speaker of (7) implies that: Simon has got something else, or someone else has got a laser printer. Different from the DM too, by the way reminds the listener that the coming utterance is a change of topic. For example:

(8) I haven't heard from my family for years. By the way, have you got the letter in your desk?

On the contrary, DMs as return to my point, back to my original point, indicate that the speaker will come back to the previous topic.

Other DMs as first, next, finally are used to inform the listener that the speaker is coming to a certain point. Such DMs should be considered as reminders of the speaker's line of thinking.

In the listening class, the researcher has illustrated those DMs and helped students understand the functions and use of DMs. Meanwhile, the researcher encourages students to pay attention to DMs when they listen to the tapes and asks them to use the theories they have learned to test the functions and use of a certain DM when it appears in the listening materials.

\subsubsection{Interaction}

"Interaction" means introduction to students discourse-sensitive activities which are designed to raise students' awareness of the interactive properties of DM use through class discussion.

At the beginning of each listening class, there is a warm-up activity which is often conducted by the teacher. Ten minutes or so is used to tell something about the knowledge of DMs related to listening materials and to organize some discussion about these DMs. These activities are used to raise students' awareness about the use of DMs and to promote their interest to pay attention to DM use in the listening materials.

For example, at the beginning of the class, the teacher introduces the DM well: one of the functions of well is used to answer a question when the speaker wants to imply the information that he is not willing or convenient to speak out. Then the students are divided into several groups to discuss: Who are the possible speakers of the following dialogue? In what context does the dialogue occur?

(9) A: Did you kill your wife?

B: Well, yes.

Through these kinds of activities and discussion, it can help students arouse their curiosity to learn DMs and help them develop the predicting skill in listening comprehension.

\subsubsection{Induction}

"Induction" is to encourage students to draw conclusions about the functions of a given DM and the capacity for noticing the differences. When students have grasped some knowledge of DMs, the teacher encourages them to summarize the functions of DMs which appear in the listening materials. In addition, according to the listening material, the teacher designs some exercises to give students more opportunities to make use of appropriate DMs.

For example, when students listen to the story Snow White, the teacher arranges an activity: Suppose you were the magic mirror, try to tell the queen in English that she is not the most beautiful woman any more. Make use of some DMs to soften your statement. This kind of training can help students induce the functions of DMs they have learned.

\subsubsection{Internalization}

"Internalization" refers to the capacity to use them on the right occasion and at the right time. After the teaching and training, students are hoped to understand DMs, pay attention to DMs in listening comprehension and use DMs on a proper way. Therefore, the teacher conducts some role playing games to test whether they have grasped DMs or not. For example: 
Tell your boyfriend or girlfriend that you are in love with someone else. Save his/her face by saying good about him or her. Use proper DMs appropriately to help you do this job.

To sum up, the researcher has utilized the method of illustration-interaction-induction -internalization to instruct and train DMs in listening class. On the other hand, using the multimedia technology, the researcher also provides students with some articles about background knowledge of DMs in Chinese, such as Review of discourse markers (Huang, 2001), Review of discourse makers in Pragmatics (Ran, 2000), etc. From the Power Point showing and introduction, students get a lot of background knowledge of DMs, such as knowledge of definitions, classifications, characterization and so on.

\subsection{Instruments}

\subsubsection{Pre-test \& Post-test}

All subjects from the Experimental Class and the Control Class are required to take a pre-test and a post-test during the whole experimental period. These two tests are given to investigate the changes of the students' listening proficiency, which may provide some clues to investigate the relationship between DMLI and students' proficiency of listening comprehension. The questions of these two listening tests are from the Question Bank of English Department of Xi'an University of Science and Technology, which has high reliability and validity. The tests of EC and CC are held respectively in the two same listening laboratories at the same time.

\subsubsection{Questionnaire}

After the post-test, the questionnaires are handed out to the EC to investigate the different effect of DMs on students who are liberal arts students and science students. The questionnaires are distributed in a language laboratory. Before students fill the questionnaires, the researcher explains the purpose of the questionnaire and asks them to finish all the questions according to their real thoughts.

The questionnaire comprises three parts. The first part is designed to obtain personal information about the participants, including age, gender, major and class. The second part consists of 10 specific questions and they can be divided into two factors: question 1 to question 5 are about the degree of attention on DMs; question 6 to question 10 are concerning the effect of DMs on listening comprehension. They are of the 5-scale Likert-type, consisting of a statement to which respondent would indicate one of the 5 -responses: $1=$ never or almost never true of me; $2=$ usually not true of me; $3=$ somewhat true of me; $4=$ usually true of me; $5=$ always or almost true of me. Therefore, the higher score a student gets, the more affirmative attitude he or she towards the statements. The third part is an open-ended question. In order to avoid any difficulties caused by the language barrier that might affect the research results, the questionnaire is written in Chinese.

\subsubsection{Observation and Interview}

Students are asked to do the exercises in their textbook- New College English Listening and Speaking (Course 1) inside class from the beginning of the semester to the end. And the researcher observes their performance in discussion, answering questions, note taking and participation in role play. Students' performance is a continual process, which can reflect the changes in terms of their listening proficiency levels.

In addition, after the post-test, the researcher has interviewed 30 science students and arts students in the EC. The main questions are: Why do you think discourse-marker devices (do not) influence your listening comprehension? Why do you think discourse-marker devices (do not) facilitate your understanding of the speaker's intention? Before the interview, the researcher informs the students that the purpose of the interview is to make an investigation and asks them to speak their minds out.

\section{Data Analysis}

\subsection{Discourse-marker-based Listening Instruction and Listening Comprehension}

\subsubsection{Pre-test}

The pre-test is carried out to test the similar level of listening proficiency between the EC and the CC. Since the pre-test is divided into three parts, the total score of the test is 30. All the scores are analyzed by SPSS 15.0. The basic information of two classes in test is shown in Table 4-1. The means of the two classes in pre-test are 15.9167 and 15.9000 respectively, which are only half of 30. The Std. Deviations of the EC and CC are about 5.2 and 5.1 .

However, only according to T-test for equality of means, can determine whether they are really similar or not in their achievements. Then, the independent samples T-test is used to analyze the scores of the pre-test between the two classes. The results are shown in Table 4-2. 
In the independent samples T-test, Levene's Test for Equality of Variances $\mathrm{F}=0.009, \mathrm{P}=0.924$, so equal variances are assumed. In the T-test for equality of means, $\mathrm{t}=0.016, \mathrm{df}=118$, and $\mathrm{P}=0.986>0.05$, there is no statistical significance. That means there is no significant difference in the achievements between the Experimental Class and the Control Class. To put it simply, the two classes are homogenous in terms of their listening comprehension proficiency before the treatment; therefore, the two classes can be comparable. After the experiment, whether and to what extent their achievements improve can be easily found.

\subsubsection{Post-test}

After 18-week instrument, students in the two classes have improved their listening proficiency. Just like the pre-test, the post-test is divided into three parts and the total score is 30 . The scores of the post-test are regarded as their proficiency and compared with each other. The basic information of two classes in post-test is shown in Table 4-3. The means of the two classes are 18.5333 and 16.4167 respectively. The mean of the EC has passed $18.00(60 \%$ of the total score), which is over 2.1 points higher than that of the CC. So, it can tentatively be assumed that students in the EC receiving the instruction of discourse markers have higher listening proficiency level than students in the CC with normal instruction. The Std. Deviations of EC and CC are about 4.5 and 5.0. The ranges of the two classes between the minimum and maximum are 21 and 22 respectively.

By comparing the two classes' scores of post-test in Table 4-4, the situation is quite different from that in the pre-test. In Levene's Test for equality of variances, we can see $\mathrm{F}=1.819$ and $\mathrm{P}=0.180$, so equal variances are assumed. In the T-test for Equality of Means, $\mathrm{t}=2.429$ and $\mathrm{P}=0.017<0.05$, there is statistical significance, which means the difference between the Experimental Class and the Control Class is quite obvious.

The results of the independent samples T-test show that the performance of the EC is really better than the CC in listening comprehension after 18-week instruction, which proves that the application of DMLI in college English listening instruction can effectively enhance students' listening proficiency.

\subsubsection{Discussion}

In order to further investigate the influence of discourse markers on listening comprehension, another investigation about the improvement of each class is made. The researcher has compared the differences within each class by the paired samples T-test to investigate whether there are significant intra-class pre-post differences. The result of the EC's is shown in Table 4-5.

The paired sample T-test shows there is significant mean difference within the EC because of $\mathrm{t}=-4.623$ and $\mathrm{P}=$ $0.000<0.05$, which means statistically significant difference between EC's pre-test and post-test. In other words, it means that this kind of teaching method is very useful and beneficial for students in the EC.

Then, the researcher has compared the Control Class in the same way. The comparison of the CC is shown in the Table 4-6.

The mean of CC2 (16.4167) is higher than CC1 (15.9000), so the CC has also made some progress in the post-test, showing the students' listening proficiency has been improved. But in the paired samples T-test, the data indicates that the means of pre- and post-tests have not reached the significant level: $\mathrm{t}=-1.650$ and $\mathrm{P}=$ $0.104>0.05$. It means that such an improvement can only be taken as a natural development in the course study. In other words, the improvement of CC's listening proficiency is not so obvious as that of EC's. The listening instruction that the CC takes is not so beneficial as that the EC takes. The results indirectly show that DMLI is more efficient.

According to the analysis of the experiment, the basic knowledge of DMs is necessary for Chinese learners and DMLI can enhance students' listening comprehension. In addition, in the experiment, the teaching method is used to train the students and the result proves that their performances in listening comprehension after the experiment are much better than before the experiment. That is to say, after a proper training, the students can have a good command of the knowledge of DMs.

Since the traditional textbooks and ways of teaching do not take DMs into account, students may not become aware of these DMs when they listen to the listening materials. Therefore, language teachers must be aware of importance of DMs and should provide students with sufficient input, as a way of improving students' listening proficiency. Based on this, whether DMLI has the same influence on students with different majors will be further explored.

\subsection{Discourse-marker-based Listening Instruction and Students with Different Majors}

\subsubsection{Performance of Students with Different Majors}

Science and liberal arts students are identical: Group1 are 30 arts students from Management School; Group2 
are 30 science students from Chemistry \& Chemical Engineering Department. The two groups' performances in the pre-test and pos-test, in the questionnaire and the interview will be analyzed to find the effect and causes.

\subsubsection{Pre-test}

The two groups' scores in pre-test are shown in Table 4-7. The maximum and minimum of arts students are higher than science students, but the mean of Group1-1 (15.4333) is lower than Group2-1 (16.4000) and the standard deviation of Group1-1 (5.15741) is lower than Group2-1 (5.28237) as well. In order to see it more clearly, one-sample T-test is utilized to analyze the relationship between Group1-1 \& Group2-1 and EC1. The result is shown in Table 4-8.

Group1-1 (arts students), $\mathrm{t}=-0.513$ and $\mathrm{P}=0.612>0.05$, there is no statistical significance. That means there is no significant difference in the achievements between the arts students and the total mean of EC. In the same way, in Group2-1 (science students), $\mathrm{t}=0.501$ and $\mathrm{P}=0.620>0.05$, there is no statistical significance, either. To put it simply, both the means of arts students and science students cannot affect the total mean of the EC in pre-test significantly; therefore, the independent samples T-test should be utilized to test whether they are really similar or not in their achievements. The details are shown in Table 4-9.

In the independent samples T-test, Levene's Test for equality of variances $\mathrm{F}=0.024, \mathrm{P}=0.878$, so equal variances are assumed. In the T-test for equality of means, $\mathrm{t}=-0.717, \mathrm{df}=58$, and $\mathrm{P}=0.476>0.05$, there is no statistical significance.

According to the Table 4-8 and 4-9, it is safe to say that there is no significant difference in the achievements between arts students and science students in pre-test. That is to say, these two groups can be comparable.

\subsubsection{Post-test}

EC has made significant improved in post-test. Then the research will continue to explore the two groups' improvement respectively. The basic information of two groups' scores in post-test is shown in Table 4-10.

Objectively speaking, arts students and science students, on the whole, have made certain progress. It is demonstrated in Table 4-10 that the maximum and minimum of arts students are still higher than science students, but at this time, the mean of Group1-2 (18.7667) is higher than Group2-2 (18.3000), so the one-sample T-test and the independent samples T-test are used to test the data. The results are shown in Table 4-11 and Table 4-12.

Group1-2 (arts students), $\mathrm{t}=0.255$ and $\mathrm{P}=0.801>0.05$, there is no statistical significance. Group2-2 (science students), $\mathrm{t}=-0.324$ and $\mathrm{P}=0.749>0.05$, there is no statistical significance either. That means that the marginal contribution of the two groups' means to the total mean of EC in post-test is not significant. The influence of the two groups' to the total mean is not significant. But in order to analyze the relationship between the two groups, we have to use the independent samples T-test. In the Table 4-12, $\mathrm{t}=0.400$ and $\mathrm{P}=0.691>0.05$, there is no statistical significance. It means the two groups don't have the significant differences in the pos-test.

In short, in the present study, the figures have indicated that the arts students and the science students have improved their listening comprehension respectively, but the means of two groups cannot affect the total mean significantly both in pre-test and post-test. In order to find the different effect on different majors, we still need the further investigation to compare the Group1-1 \& Group1-2 and Group2-1 \& Group2-2.

\subsubsection{Further Investigation}

The researcher has compared the differences within each group by the paired samples T-test to investigate whether there are significant intra-group pre-post differences.

Table 4-13 shows the means of liberal arts students in pre-test and post-test. Arts students have improved their listening proficiency because 18.7667 is higher than 15.4333 , but whether this difference is significant, the paired samples T-test must be used to examine it. In table 4-14, comparing the Group1-1 and Group1-2, $\mathrm{t}=$ -4.167 and $\mathrm{P}=0.000<0.05$, the difference is statistical significant. That is to say, DMLI is useful to liberal arts students and it can help them to improve their listening comprehension proficiency. In the same way, the researcher has tested the Group2. The comparison of the Group2 is shown in the Table 4-15 and Table 4-16.

Obviously, science students have also made progress after 18 -week instruction, because 18.3 is higher than 16.4. Then the statistical significant should be tested. In the Table $4-16, \mathrm{t}=-2.318$ and $\mathrm{P}=0.028<0.05$, it means the improvement of science students is also significant, so DMLI is useful to them as well.

According to the data, both the liberal arts students and the science students in the EC have made some progress in developing their listening comprehension proficiency through the one-semester DMLI, and this 
kind of improvement is significant. However, liberal arts students show more dramatic improvement. The performance of art students has increased by 3.3 points; science students increase by 1.9 points according to the Table 4-14 and 4-16. The figures indicate that arts students benefit more from DMLI. Apparently, DMLI in listening comprehension is useful and there are some differences between the different majors although to some extent, they all have improved.

\subsubsection{Questionnaire}

Questionnaires are distributed among the EC to explore the different influences of discourse markers on students with different majors. The questionnaire consists of ten statements that can be divided into two parts: the degree of attention on DMs ( 1 to 5) and the effect of DMs (6 to 10). Table 4-17 shows the results of the questionnaire.

The data in Table 4-17 offers a general picture of the results obtained from the questionnaire, which demonstrates different means of each question between the arts students and science students. Generally speaking, Group1 has higher means than Group2. Besides, both Group1 and Group2 hold the positive attitude towards DMs.

The first five questions are intended to check whether students pay attention to the DMs during the listening comprehension. In the first question, only $33 \%$ of arts students understand or nearly understand the listening materials during the first listening but are not manifested in their scores gained in the post-test. As a result, it can be assumed that there is something facilitating arts students.

Question 2, 3, 4 and 5 investigate whether the students notice the DMs devices or not during the listening. There are huge differences in means between two groups and the percentages can also show different attitudes towards these statements. In the second question, only $40 \%$ of Group 2 agree on noticing the DMs in the first listening while $67 \%$ admit that they have noticed DMs in the second listening. In the fourth question, $81 \%$ of Group1 are easy to find DMs in listening but only $40 \%$ of Group 2 can find them easily. Moreover, $80 \%$ of Group2 "only concentrate on the missing phases during the dialogue" in question 5 . That is to say, liberal arts students pay more attention to DMs and more sensitive to DMs during the listening comprehension than science students.

The last five questions are concerned about the effects of DMs on listening comprehension. Most students in both groups agree in these five statements that DMs devices can facilitate their interpretation, which can also affirm the first research question. However, Group2's data is still lower than Group1's.

In question 6 , there are only $41 \%$ of Group2 who agree that "DMs can help understand speaker's intention. Meanwhile, $92 \%$ of Group1 agree on this statement, so they get higher means (4.5) of this question than that of Group2 (3.6). The same situation has happened in question 7 and question 8. Most students in Group1 affirm that DMs devices give them hints during the listening, which also indicates DMs help them to further understand the listening comprehension. Objectively speaking, DMs can affect arts students more significantly. As for the last question, most students in Gruop1 (90\%) and Group2 (80\%) believe that DMs should be taught in the college English listening class.

From the above data, most students agree that DMLI affects their listening comprehension and liberal arts students are easily affected, because students value DMs differently and have different attitudes. According to arts students, they attach importance and pay special attention to DMs devices so that DMs can give them more hints and facilitate their listening comprehension. Therefore, they benefit from DMLI more.

On the basis of the questionnaire's results, the students' performance in the interview will be examined to find the causes.

\subsubsection{Observation and Interview}

During the whole teaching semester, the researcher has observed the performance of the EC carefully. Through the observation, the researcher also finds that subjects' attitudes to DMLI are various and that has been reflected in the questionnaire.

In the class instruction, liberal arts students seem to be more interested in the theories and functions of discourse markers; most of them take notes, participate the class discussion actively and can find some questions to ask. On the other hand, most science students show no interest in it, although they have finished all the exercises and assignments as well.

Therefore, the interview has interviewed several science students and arts students to explore their true feelings. Science students hold the view that DMs play a minor role in their listening comprehension. According to their 
responses, they think they can easily understand the logic and the intention of the speakers, so they are not inclined to notice the expressions although the teacher often emphasizes similar expressions in the listening class. They think that the expressions are made up simple words, and their meanings are very obvious. In fact, only the difficult phrases and sentences can attract their attention. They admit that sometimes some of the expressions of DMs can help them to understand the intention of the speakers, especially "I think" and "in my opinion". However, this kind of help is limited that it does not influence the understanding of the listening materials.

On the other hand, this is not the case with arts students. Their verbal statements also further explain the important role of DMs in their listening comprehension. They believe that in the usual listening class, the teacher always reminds them of some special expressions and ask them to guess the meaning of the new words, to predict the meaning of the following sentence and to notice the coherence of the whole passages by using these expressions. Gradually, they have formed a habit of paying more attention to these short words and phrases occurring at the initial position of sentences or at the end. What' more, DMs give them a hint of the listening comprehension and help them build the logical relationship in the listening materials.

\subsubsection{Discussion}

Both the arts students and science students have improved in post-test. According to the analysis, after gaining DMLI, Group1 makes a very significant improvement (Table 4-14: $\mathrm{P}=0.000<0.05$ ) from the pre-test to the post-test, and Group2 also makes significant improvement (Table 4-16: $\mathrm{P}=0.028<0.05$ ). That means DMLI are useful to both arts students and science students.

However, in the pre-test, the mean of Group1 is lower than Group2; but in post-test, the mean of Group1 is higher than Group2; moreover, Group1 has increased by 3.3 points; Group2 only increases by 1.9 points, although this kind of improvement is statistical significant. In addition, according to the questionnaires, the observation and interview in the class, students' behaviors and statements further prove that DMs have different effect on them, because liberal arts students and science students have different thinking modes. For science students, they are good at abstract thinking and logical thinking; and in their mind, it is easy to build up a "logical map" when they are listening to the listening materials, so they usually do not pay much attention to DMs and the functions of DMs seem to be not fairly obvious. However, on the other hand, for liberal arts students, they are not like science students and sometimes their thinking are not so clear and logical when they are listening to some academic passages, so DMs can help them to build up the "logical map" in listening comprehension. That is to say, DMLI is more helpful to them and guided by these expressions, they can easily concentrate on listening and understand the speakers' implied meaning; therefore, they have paid more attention to DMs in listening. Because of the different thinking modes of arts students and science students, arts students are more interested in and pay more attention to DMs in listening. Objectively speaking, comparing with science students, DMLI is more useful to arts students.

\subsection{Findings of the Study}

The results are obtained through both quantitative and qualitative analyses. The major findings of the research are as follows:

1. Discourse-marker-based listening instruction can improve non-English major students' listening proficiency.

2. Discourse-marker-based listening instruction is useful to liberal arts students and science students and both of them have the significant improvement.

3. Liberal arts students benefit more significantly from DMLI

These findings show that discourse markers facilitate students' listening comprehension and can enhance their listening proficiency to a great extent.

\section{Conclusion}

The study illustrates how theoretical model can be applied to classroom practices, and the results of the study have their implications in listening comprehension.

Firstly, the study engages in bridging the gap between the theories of DMs and listening comprehension. DMs can possibly make contribution to listening comprehension, but in college English listening class, DMs and its contribution are often neglected. So it is necessary to properly apply DMs to English listening comprehension instruction.

Secondly, the statistical analysis of scores in two tests shows that listening comprehension of the students in 
the Experimental Class is significantly improved by gaining DMLI. That means DMs play an important role in listening comprehension. Therefore, the pedagogical implication that can be drawn from this study is that DMs should be treated as a part of listening comprehension instruction and integrated into listening class. In listening class, merely listening to tapes and checking answer are not enough for students to develop their listening proficiency, so college English teachers should teach students how to interpret by themselves, just as that saying goes "Giving a man a fish, he will eat for a day; teach him how to fish, he can eat all his life".

Thirdly, the results of tests, questionnaires, class observation and the interview reveal that DMLI has different effect on different majors. DMLI is more useful to liberal arts students. They pay more attention to DMs. Guided by DMs, they can better concentrate on listening and easier get speaker's intention. So to learners - subjects of arts, mastering DMs are very helpful in developing their proficiency of listening. In the long run, properly noticing helps students become more efficient learners, take more responsibility for self-directing their learning and gain more confidence in learning English.

Finally, the study proves the positive effects to DMs by the practical experiment in listening comprehension instruction. However, according to some science students' questionnaires, DMs to some extent have a certain negative influence, resulting in missing some key information. So, a task-based approach to instruction should be adopted. This approach should maximize the chances of focus on form through attentive manipulation so that a balance is kept between form and meaning and alternative attention is paid to both. In task-based instruction, the design and planning of tasks should be guided by the principle that various tasks must be covered. And attention should be channeled to both form and meaning of DMs in listening comprehension. It is the combination of guidance of proper theories, appropriate listening skills and strategies, and immense listening practice that makes a successful listener possible.

\section{References}

Aijmer, K. (2002). English Discourse Particles-Evidence from a Corpus. John Benjamins Publishing Company.

Andersen, G. (2001). Pragmatic Makers and Sociolinguistic Variation: A Relevance-theoretic Approach to the Language of Adolescents. Amsterdam: John Benjamins.

Anderson, A., \& A. Lynch. (1988). Listening. Oxford: Oxford University Press.

Anderson, E. S., Brizuela, M., Dupuy, B., \& Gonnerman, L. (1999). Cross-linguistic evidence for the early acquisition of discourse markers as register variable. Journal of Pragmatics, 31, 1339-1351. http://dx.doi.org/10.1016/S0378-2166(98)00108-8

Bazanella, C. (2000). Phatic connectives as interactional cues in contemporary spoken Italian. Journal of Pragmatics, 14, 629-647. http://dx.doi.org/10.1016/0378-2166(90)90034-B

Beauvais, Paul. (1999). A speech act theory of metadiscourse. Written Communication, 61, 157-165. http://dx.doi.org/10.1177/0741088389006001002

Blakemore, D. (1987). Constraint on Relevance. Oxford: Blakewell.

Blakemore, D. (1992). Understanding Utterance. Oxford: Blakewell.

Blakemore, D. (1996). Are apposition markers discourse markers. Journal of Linguistics, 32, 325-347. http://dx.doi.org/10.1017/S0022226700015917

Brown, G. (1990). Listening to Spoken English. London: Longman.

Brown, G., \& J. Yule. (1983). Discourse Analysis. Cambridge: Cambridge University Press.

Chaudron, C., \& J. C. Richards. (1996). The effect of discourse markers on the comprehension of lectures. Applied Linguistics, 7, 20-35. http://dx.doi.org/10.1093/applin/7.2.113

Chen, Y., \& He, W. (2001). Dui bu dui as a pragmatic discourse. Journal of Pragmatics, 33, 1441-1465. http://dx.doi.org/10.1016/S0378-2166(00)00084-9

Crisemore, A. (1990). Metadiscourse and discourse process: interaction and issues. Discourse Process, 13, 191-205. http://dx.doi.org/10.1080/01638539009544753

Dunkel, P. A. (2001). Listening in the native and second/foreign language: toward an integration of research and practice. TESOL Quarterly, 25(3), 431-457. http://dx.doi.org/10.2307/3586979

Erman, B. (2001). Pragmatic markers revisited with a focus on you know in adult and adolescent talk. Journal of Pragmatics, 31, 1337-1359. http://dx.doi.org/10.1016/S0378-2166(00)00066-7 
Field, J. (1998). Skill and strategies: towards a new methodology for listening. ELT Journal, 52(2), 110-118. http://dx.doi.org/10.1093/elt/52.2.110

Fraser, B. (1988). Types of English discourse markers. Acta Linguistica Hungarica, 38(4), 19-33

Fraser, B. (1990). An approach to discourse markers. Journal of Pragmatics, 14, 383-395. http://dx.doi.org/10.1016/0378-2166(90)90096-V

Fraser, B. (1999). What are discourse markers? Journal of Pragmatics, 31, 931-952. http://dx.doi.org/10.1016/S0378-2166(98)00101-5

Fuller, J. M. (2003). The influence of speaker role on discourse markers use. Journal of Pragmatics, 35, 23-45. http://dx.doi.org/10.1016/S0378-2166(02)00065-6

Halliday, \& Hassan. (1976). Cohesion in English. London: Longman.

Hansen, M. (1997). Alors and donc in spoken French: a reanalysis. Journal of Pragmatics, 28, 153-187. http://dx.doi.org/10.1016/S0378-2166(96)00086-0

Hellermann, J. (2007). Language which is not taught: The discourse marker use of beginning adult learners of English. Journal of Pragmatics, 1,157-179. http://dx.doi.org/10.1016/j.pragma.2006.04.008

Jucker, A., \& Y. Ziv. (1998). Discourse Markers: Description and Theory. Amsterdam: John Benjamins.

Knott, A., \& T. Sanders. (1998). The classification of coherence relations and their linguistic markers: an exploration of two languages. Journal of Pragmatics, 30, 135-175. http://dx.doi.org/10.1016/S0378-2166(98)00023-X

Krashen, S. (1982). Principles and Practice in Second Language Acquisition. Oxford: Pergamon Press.

Macaulay, R. (2002). You know, it depends. Journal of Pragmatics, 34, 749-767. http://dx.doi.org/10.1016/S0378-2166(01)00005-4

Norrick, N. R. (2002). Discourse markers in oral narrative. Journal of Pragmatics, 35, 849-878. http://dx.doi.org/10.1016/S0378-2166(01)80032-1

O’Malley, J. M., \& A. U. Chamot. (1990). Learning Strategies in Second Language Acquisition. Cambridge: Cambridge University Press.

Redeker, G. (1991). Linguistics markers of discourse structure. Linguistics, 29, 1139-1172

Risselada, R., \& W. Spooren. (1998). Introduction: Discourse markers and coherence relation. Journal of Pragmatics, 30, 131-133. http://dx.doi.org/10.1016/S0378-2166(98)00022-8

Rost, M. (1990). Listening in Language Learning. New York: Longman.

Rubin, J. (1994). A review of second language listening comprehension research. Modern Language Journal, 78(2), 199-221. http://dx.doi.org/10.2307/329010

Schiffrin, D. (1987). Discourse Markers. Cambridge: Cambridge University Press.

Sperber, D., \& D. Wilson, (2001) Relevance: Communication and Cognition. Beijing: Foreign Language Teaching and Research Press.

Taboada, M. (2006). Discourse markers as signals (or not) of rhetorical relations. Journal of Pragmatics, 38, 567-592. http://dx.doi.org/10.1016/j.pragma.2005.09.010

Underwood, M. (1989). Teaching Listening. London: Longman.

Wilson, D. (2000). Relevance and communication. Modern Foreign Language, 2, 200-217. http://dx.doi.org/10.1902/jop.2008.080172

Xu, H. M. (2001). Metadiscourse: Across-cultural Perspective. Nanjing: Southeast University Press.

Table 1. The scores of two classes in pre-test

\begin{tabular}{ccccccc}
\hline Group & N & Minimum & Maximum & Range & Mean & Std. Deviation \\
\hline EC & 60 & 6.00 & 26.00 & 20.00 & 15.9167 & 5.19873 \\
CC & 60 & 6.00 & 26.00 & 20.00 & 15.9000 & 5.12455 \\
\hline
\end{tabular}


Table 2. The independent samples T-test of pre-test

\begin{tabular}{c|c|c|c|c|c|c|c}
\hline \multirow{2}{*}{ Group } & \multirow{2}{*}{ Mean } & & \multicolumn{2}{|c}{$\begin{array}{c}\text { Levene's Test for } \\
\text { Equality of Variances }\end{array}$} & \multicolumn{4}{|c}{ t-test } \\
\cline { 3 - 7 } & & $\mathrm{F}$ & Sig. & $\mathrm{t}$ & $\mathrm{Df}$ & Sig. (2-tailed) \\
\hline $\mathrm{EC}$ & 15.9167 & $\begin{array}{c}\text { Equal } \\
\text { variances } \\
\text { assumed }\end{array}$ & .009 & .924 & .016 & 118 & .986 \\
$\mathrm{CC}$ & 15.9000 & & & & & & \\
\hline
\end{tabular}

Table 3. The scores of two classes in post-test

\begin{tabular}{ccccccc}
\hline Group & $\mathrm{N}$ & Minimum & Maximum & Range & Mean & Std. Deviation \\
\hline EC & 60 & 5.00 & 26.00 & 21.00 & 18.5333 & 4.48526 \\
CC & 60 & 4.00 & 26.00 & 22.00 & 16.4167 & 5.04318 \\
\hline
\end{tabular}

Table 4. The independent samples T-test of post-test

\begin{tabular}{|c|c|c|c|c|c|c|c|}
\hline \multirow[t]{2}{*}{ Group } & \multirow[t]{2}{*}{ Mean } & & \multicolumn{2}{|c|}{$\begin{array}{r}\text { Levene's Test for } \\
\text { Equality of Variances }\end{array}$} & \multicolumn{3}{|c|}{ t-test } \\
\hline & & & $\mathrm{F}$ & Sig. & $\mathrm{t}$ & $\mathrm{df}$ & Sig. (2-tailed) \\
\hline $\begin{array}{l}\mathrm{EC} \\
\mathrm{CC}\end{array}$ & $\begin{array}{l}18.5333 \\
16.4167\end{array}$ & $\begin{array}{c}\text { Equal } \\
\text { variances } \\
\text { assumed }\end{array}$ & 1.819 & .180 & 2.429 & 118 & .017 \\
\hline
\end{tabular}

Table 5. Paired samples test of EC

\begin{tabular}{|c|c|c|c|c|c|c|c|c|}
\hline & \multicolumn{5}{|c|}{ Paired Differences } & \multirow{3}{*}{$\mathrm{t}$} & \multirow{3}{*}{$\mathrm{df}$} & \multirow{3}{*}{$\begin{array}{c}\text { Sig.( } \\
\text { 2-tail } \\
\text { ed) }\end{array}$} \\
\hline & \multirow{2}{*}{ Mean } & \multirow{2}{*}{$\begin{array}{c}\text { Std. } \\
\text { Deviation }\end{array}$} & \multirow{2}{*}{$\begin{array}{l}\text { Std. } \\
\text { Error } \\
\text { Mean }\end{array}$} & \multicolumn{2}{|c|}{$\begin{array}{c}95 \% \text { Confidence Interval of } \\
\text { the Difference }\end{array}$} & & & \\
\hline & & & & Lower & Upper & & & \\
\hline EC1-EC2 & -2.61667 & 4.38446 & .56603 & -3.74929 & -1.48404 & -4.623 & 59 & .000 \\
\hline
\end{tabular}

Note: EC1=EC's pre-test $\quad$ EC2=EC's post-test

Table 6. Paired samples test of CC

\begin{tabular}{|c|c|c|c|c|c|c|c|c|}
\hline & \multicolumn{5}{|c|}{ Paired Differences } & \multirow{3}{*}{$\mathrm{t}$} & \multirow{3}{*}{$\mathrm{df}$} & \multirow{3}{*}{$\begin{array}{l}\text { Sig.(2- } \\
\text { tailed) }\end{array}$} \\
\hline & \multirow[t]{2}{*}{ Mean } & \multirow[t]{2}{*}{$\begin{array}{c}\text { Std. } \\
\text { Deviation }\end{array}$} & \multirow[t]{2}{*}{$\begin{array}{l}\text { Std. Error } \\
\text { Mean }\end{array}$} & \multicolumn{2}{|c|}{$\begin{array}{c}\text { 95\% Confidence } \\
\text { Interval of the } \\
\text { Difference }\end{array}$} & & & \\
\hline & & & & Lower & Upper & & & \\
\hline $\mathrm{CC} 1-\mathrm{CC} 2$ & -.51667 & 2.42509 & .31308 & -1.14313 & .10980 & -1.650 & 59 & .104 \\
\hline
\end{tabular}

\footnotetext{
Note: $\mathrm{CC} 1=\mathrm{CC}$ 's pre-test $\quad \mathrm{CC} 2=\mathrm{CC}$ 's post-test
} 
Table 7. The scores of two groups in pre-test

\begin{tabular}{ccccccc}
\hline & $\mathrm{N}$ & Minimum & Maximum & Range & Mean & Std. Deviation \\
\hline Group1-1 & 30 & 7.00 & 26.00 & 19.00 & 15.4333 & 5.15741 \\
Group2-1 & 30 & 6.00 & 25.00 & 19.00 & 16.4000 & 5.28237 \\
\hline
\end{tabular}

Note: Group 1-1= arts students, Group2-1= science students

Table 8. One-sample T-test in pre-test

\begin{tabular}{c|c|c|c}
\hline \multirow{2}{*}{} & \multicolumn{3}{|c}{ Test Value =15.9167 } \\
\cline { 2 - 4 } & $\mathrm{t}$ & $\mathrm{df}$ & Sig. (2-tailed) \\
\hline Group1-1 & -.513 & 29 & .612 \\
\hline Group2-1 & .501 & 29 & .620 \\
\hline
\end{tabular}

Table 9. The independent samples T-test of two groups

\begin{tabular}{|c|c|c|c|c|c|}
\hline & \multicolumn{2}{|c|}{$\begin{array}{c}\text { Levene's Test for Equality of } \\
\text { Variances }\end{array}$} & \multicolumn{3}{|c|}{ t-test } \\
\hline & $\mathrm{F}$ & Sig. & $\mathrm{t}$ & Df & Sig. (2-tailed) \\
\hline $\begin{array}{c}\text { Equal variances } \\
\text { assumed }\end{array}$ & .024 & .878 & -.717 & 58 & .476 \\
\hline
\end{tabular}

Table 10. The scores of two groups in post-test

\begin{tabular}{lllllll}
\hline & N & Minimum & Maximum & Range & Mean & $\begin{array}{c}\text { Std. } \\
\text { Deviation }\end{array}$ \\
\hline Group1-2 & 30 & 7.00 & 26.00 & 19.00 & 18.7667 & 5.02191 \\
Group2-2 & 30 & 5.00 & 24.00 & 19.00 & 18.3000 & 3.94925 \\
\hline
\end{tabular}

Note: Group1-2= arts students, Group2-2= science students

Table 11. One-sample T-test in post-test

\begin{tabular}{c|c|c|c}
\hline \multirow{2}{*}{} & \multicolumn{3}{|c}{ Test Value $=18.5333$} \\
\cline { 2 - 4 } & $\mathrm{t}$ & $\mathrm{df}$ & Sig. (2-tailed) \\
\hline Group1-2 & .255 & 29 & .801 \\
\hline Group2-2 & -.324 & 29 & .749 \\
\hline
\end{tabular}

Table 12. The independent samples T-test of two groups

\begin{tabular}{l|c|c|c|c|c}
\hline \multirow{2}{*}{} & \multicolumn{2}{|c|}{$\begin{array}{c}\text { Levene's Test for } \\
\text { Equality of Variances }\end{array}$} & \multicolumn{4}{|c}{ t-test } \\
\cline { 2 - 7 } & $\mathrm{F}$ & Sig. & t & Df & Sig. (2-tailed) \\
\hline Equal variances assumed & 3.524 & .066 & .400 & 58 & .691 \\
\hline
\end{tabular}


Table 13. Paired sample statistics of Group1

\begin{tabular}{cccc}
\hline & Mean & N & Std. Deviation \\
\hline Group1-1 & 15.4333 & 30 & 5.15741 \\
Group1-2 & 18.7667 & 30 & 5.02191 \\
\hline
\end{tabular}

Table 14. Paired samples T-test of Group1

\begin{tabular}{|c|c|c|c|c|c|c|c|c|}
\hline & \multicolumn{5}{|c|}{ Paired Differences } & \multirow{3}{*}{$\mathrm{t}$} & \multirow{3}{*}{$\mathrm{df}$} & \multirow{3}{*}{$\begin{array}{l}\text { Sig.( } \\
\text { 2-tail } \\
\text { ed) }\end{array}$} \\
\hline & \multirow[t]{2}{*}{ Mean } & \multirow{2}{*}{$\begin{array}{c}\text { Std. } \\
\text { Deviation }\end{array}$} & \multirow{2}{*}{$\begin{array}{l}\text { Std. } \\
\text { Error } \\
\text { Mean }\end{array}$} & \multicolumn{2}{|c|}{$\begin{array}{c}95 \% \text { Confidence Interval of } \\
\text { the Difference }\end{array}$} & & & \\
\hline & & & & Lower & Upper & & & \\
\hline $\begin{array}{l}\text { Group1-1 } \\
\text { Group1-2 }\end{array}$ & -3.33333 & 4.38126 & .79990 & -4.96932 & -1.69735 & -4.167 & 29 & .000 \\
\hline
\end{tabular}

Table 15. Paired sample statistics of Group2

\begin{tabular}{cccc}
\hline & Mean & N & Std. Deviation \\
\hline Group2-1 & 16.4000 & 30 & 5.28237 \\
Group2-2 & 18.3000 & 30 & 3.94925 \\
\hline
\end{tabular}

Table 16. Paired samples T-test of Group2

\begin{tabular}{|c|c|c|c|c|c|c|c|c|}
\hline & \multicolumn{5}{|c|}{ Paired Differences } & \multirow{3}{*}{$\mathrm{t}$} & \multirow{3}{*}{$\mathrm{df}$} & \multirow{3}{*}{$\begin{array}{c}\text { Sig.( } \\
\text { 2-tail } \\
\text { ed) }\end{array}$} \\
\hline & \multirow{2}{*}{ Mean } & \multirow{2}{*}{$\begin{array}{c}\text { Std. } \\
\text { Deviation }\end{array}$} & \multirow{2}{*}{$\begin{array}{l}\text { Std. } \\
\text { Error } \\
\text { Mean }\end{array}$} & \multicolumn{2}{|c|}{$\begin{array}{l}95 \% \text { Confidence Interval of } \\
\text { the Difference }\end{array}$} & & & \\
\hline & & & & Lower & Upper & & & \\
\hline $\begin{array}{l}\text { Group2-1G } \\
\text { roup2-2 }\end{array}$ & -1.90000 & 4.49022 & .81980 & -3.57668 & -.22332 & -2.318 & 29 & .028 \\
\hline
\end{tabular}

Table 17. Results of the questionnaire

\begin{tabular}{|c|c|c|c|c|c|c|c|c|c|c|c|}
\hline \multirow{2}{*}{ Group } & \multicolumn{10}{|c|}{ Mean of each question } & \multirow{2}{*}{ Total } \\
\cline { 2 - 12 } & 1 & 2 & 3 & 4 & 5 & 6 & 7 & 8 & 9 & 10 & \\
\hline Group1 & 2.9 & 3.8 & 4.3 & 4.2 & 3.4 & 4.5 & 4.8 & 4.1 & 4.5 & 4.4 & 40.9 \\
\hline Group2 & 3.8 & 3.6 & 3.7 & 3.4 & 4.0 & 3.6 & 4.0 & 3.2 & 4.0 & 4.2 & 37.5 \\
\hline & \multicolumn{10}{|c|}{ Percentage of agreement on each question } \\
\hline Group1 & $33 \%$ & $55 \%$ & $83 \%$ & $81 \%$ & $30 \%$ & $92 \%$ & $95 \%$ & $80 \%$ & $90 \%$ & $90 \%$ & \\
\hline Group2 & $65 \%$ & $40 \%$ & $67 \%$ & $40 \%$ & $80 \%$ & $41 \%$ & $82 \%$ & $60 \%$ & $80 \%$ & $80 \%$ & \\
\hline
\end{tabular}

Note: Group $1=$ arts students, Group $2=$ science students 